\title{
Extended Bandwidth Method on Symmetrical Operational Transconductance Amplifier and Filter Application
}

\author{
Mustafa Konal', Firat Kacar ${ }^{2}$
}

${ }^{1}$ Tekirdag Namik Kemal University, Electronics and Telecommunication Engineering Department, Tekirdag, Turkey

${ }^{2}$ Istanbul University-Cerrahpasa, Electrical and Electronics Engineering Department, Istanbul, Turkey

\begin{abstract}
In this paper, a method for extending the bandwidth of a symmetrical operational transconductance amplifier (OTA) circuit is proposed. Resistive compensation technique is applied to all current mirrors of the symmetrical OTA circuit. A passive resistor is connected between the gate and the drain of each primary transistor of the current mirrors in the symmetrical OTA structure. The performance of the proposed OTA with extended transconductance bandwidth is analyzed by implementing filter structures. The advantage of using the resistive compensation technique is demonstrated. The proposed symmetrical OTA and the filters are simulated with LTSPICE by using TSMC $0.18 \mu \mathrm{m}$ CMOS process parameters.
\end{abstract}

Keywords: Symmetrical OTA, Extended bandwidth, Filter, Resistive compensation technique

\section{Metoda razširjene pasovne širine na simetričnem operacijskem ojačevalniku in filtru}

Izvleček: $\vee$ članku je predlagana metoda za razširitev pasovne širine vezja simetričnega ojačevalnika (OTA). Tehnika uporovne kompenzacije je uporabljena na vseh zrcalih simetričnega vezja OTA. Pasivni upor je vezan med vrati in ponorom vsakega primarnega tranzistorja trenutnih zrcal v simetrični OTA strukturi. Učinkovitost predlaganega OTA z razširjeno pasovno širino transkonduktance je analizirana z uporabo filtrirnih struktur. Dokazana je prednost uporabe uporovne kompenzacijske tehnike. Predlagani simetrični OTA in filtri so simulirani z LTSPICE v TSMC 0,18 $\mu$ m CMOS tehnologiji.

Ključne besede: Simetrični OTA, razširjena pasovna širina, filter, tehnika uporovne kompenzacije

*Corresponding Author's e-mail:mkonal@nku.edu.tr

\section{Introduction}

Operational transconductance amplifiers (OTA) are significant active elements for continuous-time signal processing applications. In the literature, many OTA based circuit blocks such as filters [1-6], oscillators [7-9], mem-elements [10-11] and inductance simulators [1214] etc. have been reported. For several applications operating at high frequencies, it is necessary to use integrated circuits with wide bandwidth. Therefore, a resistive compensation technique can be used to widen bandwidth of the circuits [15-17]. A wide bandwidth second-generation current conveyor based four-quadrant mixed mode analogue multiplier is presented in [15]. A conventional low voltage cascode current mirror is analyzed in [16].

In this paper, a symmetrical operational transconductance amplifier with extended transconductance bandwidth is proposed. Resistive compensation technique is applied to the current mirrors of the OTA in order to increase the transconductance bandwidth. The transconductance of the OTA can be adjusted electronically by 
changing the biasing current and resistive compensation technique can be applied to the circuit with different resistor values. Temperature performance of the OTA is analyzed for different temperatures. In addition, in order to demonstrate the performance of the proposed OTA, it is used in a second order low-pass filter structure. Both symmetrical OTA and filter circuits are analyzed with LTSPICE using $0.18 \mu \mathrm{m}$ TSMC CMOS process parameters.

\section{Extended bandwidth symmetrical} OTA

Resistive compensation technique is applied to the symmetrical OTA in order to extend its bandwidth. A passive resistor is connected between the gate and drain of each main transistor of the current mirrors in the presented symmetrical OTA. The current mirror circuits without and with resistive compensation are given in Fig. 1a and Fig. $1 \mathrm{~b}$.

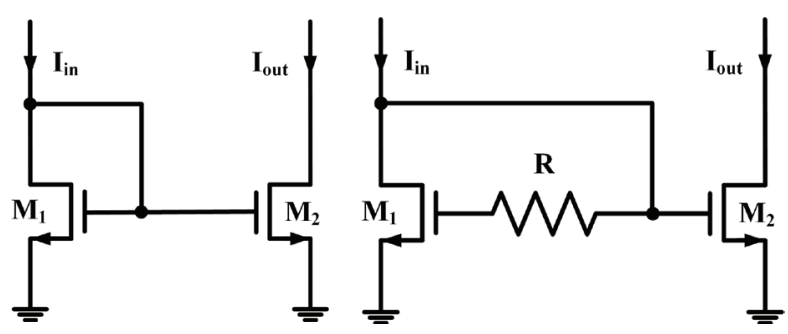

(a)

(b)

Figure 1: Simple current mirror (a) without resistive compensation (b) with resistive compensation.

Small signal models of the simple current mirrors without and with resistive compensation are given in Fig. $2 a$ and Fig. 2b, respectively.

(a)

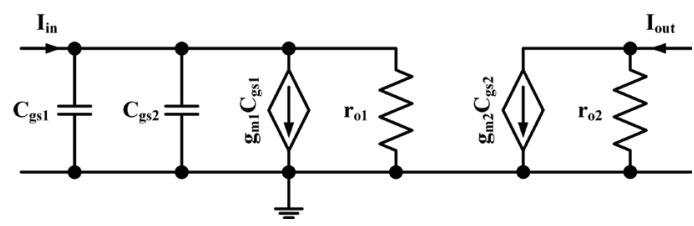

(b)

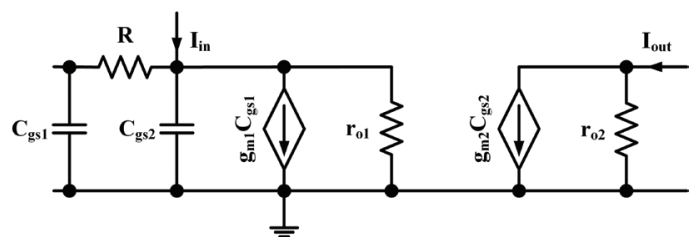

Figure 2: Small-signal model of the current mirrors (a) without resistive compensation (b) with resistive compensation.

By considering transistors $M_{1}$ and $M_{2}$ are identical, the relationship between the input and the output cur- rents is given in [15] as the following equations for the simple current mirror circuit for which the equivalent circuit given in Fig. $2 \mathrm{a}\left(C_{g s 1}=C_{g s 2}=C_{g s^{\prime}} r_{o 1}=r_{o 2}=r_{o^{\prime}} g_{m 1}=\right.$ $\left.g_{m 2}=g_{m}\right)$. The bandwidth of the circuit depends on the gate-source capacitance $C_{g s}$ and transconductance $g_{m}$ as given in Eq (2) [15].

$$
\frac{I_{\text {out }}}{I_{\text {in }}}=\frac{1}{s \frac{2}{g_{m}} C_{g s}+1}
$$

$\omega_{0}=\frac{g_{m}}{2 C_{g s}}, \quad f_{0}=\frac{g_{m}}{4 \pi C_{g s}}$

After the resistive compensation technique is applied to a simple current mirror (equivalent circuit given in Fig. 2b), the relationship between the input and the output currents is given by Eq (3) [15]. By choosing the value of resistor as $R=1 / g_{m^{\prime}}$ the expression for frequency as given in Eq (4) is obtained. It can be seen from the equation that the bandwidth of the current mirror with compensation technique is increased by a factor of two compared to the simple current mirror [15].

$$
\frac{I_{\text {out }}}{I_{\text {in }}}=\frac{s R C_{g s}+1}{s^{2} \frac{R}{g_{m}} C_{g s}^{2}+s \frac{\left(2 r_{o}+R\right)}{r_{o} g_{m}} C_{g s}+1}
$$

$\omega_{0}=\frac{g_{m}}{C_{g s}}, \quad f_{0}=\frac{g_{m}}{2 \pi C_{g s}}$

The symbol and the CMOS realization of a symmetrical OTA with extended transconductance bandwidth are shown in Fig. 3a and Fig. 3b, respectively. The terminal relations of the symmetrical OTA is given by Eq (5) as follows;

$$
I_{o}=g_{m}\left(V_{i}^{+}-V_{i}^{-}\right)
$$

The supply voltages and biasing current are chosen as $V_{D D}=-V_{S S}=1.5 \mathrm{~V}$ and $I_{B}=400 \mu \mathrm{A}$, respectively. The transconductance of the OTA is calculated as $1.02 \mathrm{~mA} / \mathrm{V}$ and the passive resistors are taken as $R_{P 1}=R_{P 2}=R_{N}=1 /$ $g_{m}=980 \Omega$. The aspect ratios of the transistors are given in Table 1. The frequency dependence of the transconductances of a symmetrical OTA without and with resistive compensation is given in Fig. $4 a$ and the zoomedin version is shown in Fig. $4 \mathrm{~b}$. It can be seen that the bandwidth of the $g_{m}$ is extended by approximately . 


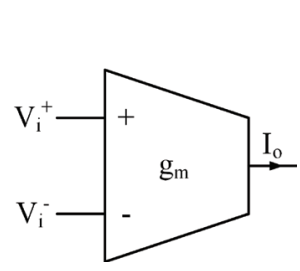

(a)

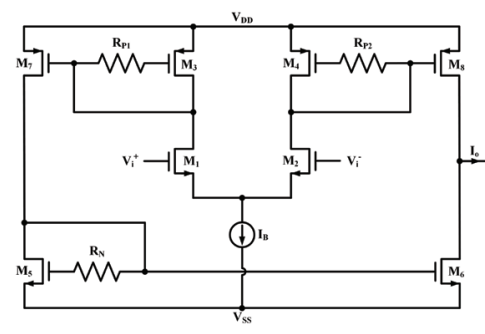

(b)
Figure 3: a) Circuit symbol b) CMOS realization of a symmetrical OTA with extended transconductance bandwidth.

(a)

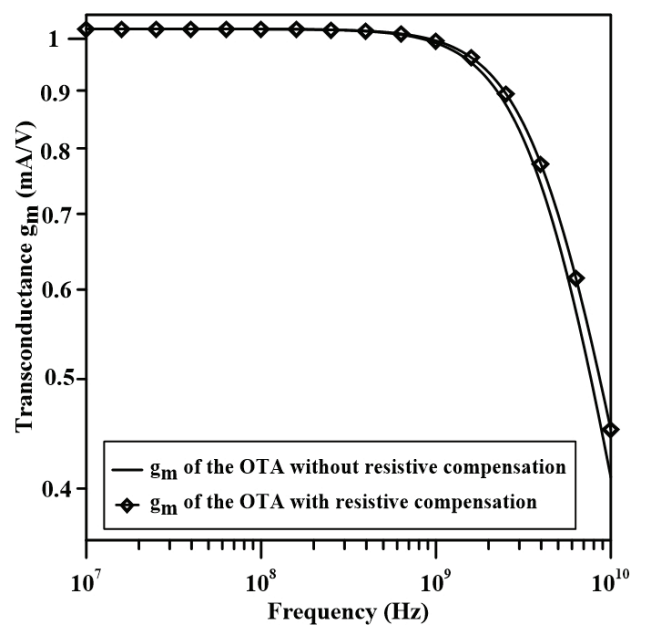

(b)

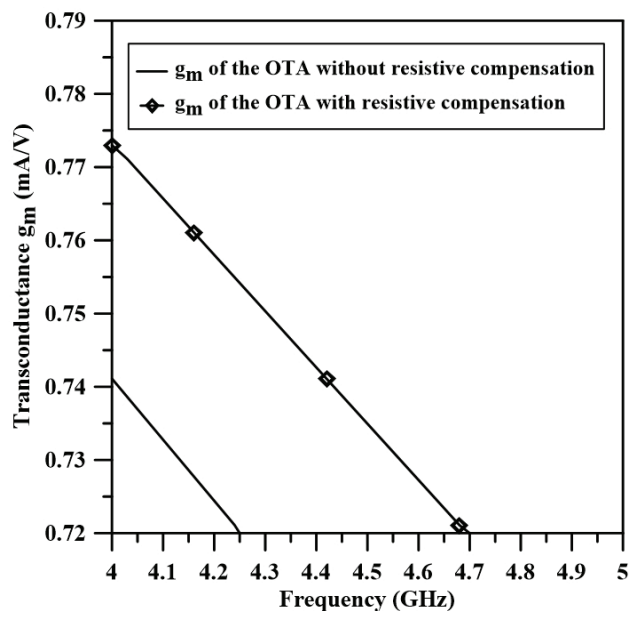

Figure 4: (a) Transconductances of the symmetrical OTA without and with resistive compensation (b) zoomed-in version.

The transconductance of the OTA can be adjusted by changing the biasing current $I_{B}$. For values of biasing current $50 \mu \mathrm{A}, 100 \mu \mathrm{A}, 200 \mu \mathrm{A}$ and $400 \mu \mathrm{A}$ the transconductance of the symmetrical OTA is $796.9 \mu \mathrm{A} V$, $925.4 \mu \mathrm{A} / \mathrm{V}, 986.5 \mu \mathrm{A} / \mathrm{V}$ and $1.02 \mathrm{~mA} / \mathrm{V}$, respectively. The dependence of transconductance on the value of compensation resistor is depicted in Fig. 5. In order to make the circuit suitable for analog integrated circuit implementations passive resistors can be replaced by MOS resistors.

Table 1: Transistors aspect ratios.

\begin{tabular}{|c|c|c|}
\hline Transistors & $W(\mu \mathrm{m})$ & $L(\mu \mathrm{m})$ \\
\hline $\mathrm{M}_{1}, \mathrm{M}_{2}$ & 0.72 & 0.18 \\
\hline $\mathrm{M}_{3}, \mathrm{M}_{4}, \mathrm{M}_{5}, \mathrm{M}_{6}$ & 1.8 & 0.18 \\
\hline $\mathrm{M}_{7}, \mathrm{M}_{8}$ & 5.4 & 0.18 \\
\hline $\mathrm{V}_{\mathrm{DD}}=-\mathrm{V}_{\mathrm{SS}}=1.5 \mathrm{~V}, \mathrm{I}_{\mathrm{B}}=400 \mu \mathrm{A}, \mathrm{R}_{\mathrm{P} 1}=\mathrm{R}_{\mathrm{P} 2}=\mathrm{R}_{\mathrm{N}}=980 \Omega$ \\
\hline
\end{tabular}

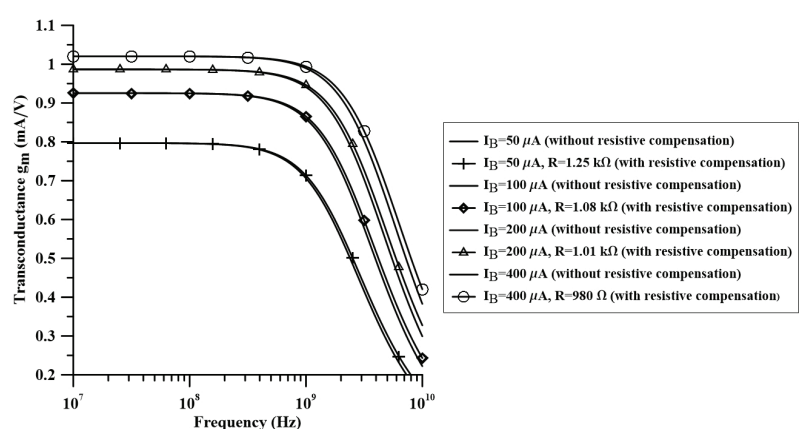

Figure 5: Transconductance gains of the symmetrical OTA without and with resistive compensation for different biasing currents.

The temperature performance of the symmetrical OTA with resistive compensation is simulated for the resistor values of $1.25 \mathrm{k} \Omega$ and $980 \Omega$ for various temperatures from $0^{\circ} \mathrm{C}$ to $100^{\circ} \mathrm{C}$ as shown in Fig. 6 . It can be seen from the figure that the transconductance of the OTA decreases with increasing temperature.

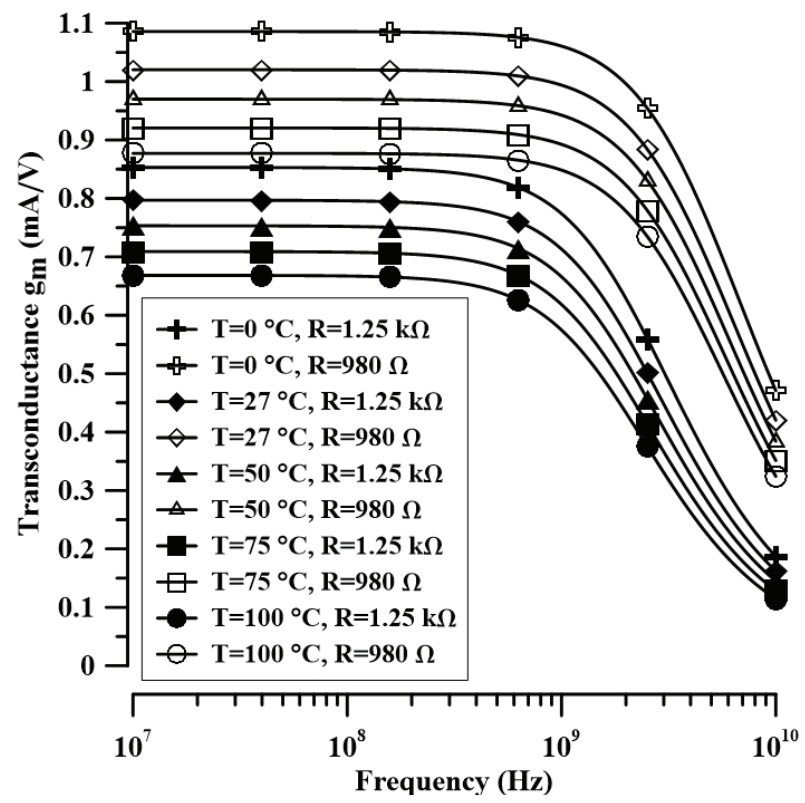

Figure 6: Temperature performance of the symmetrical OTA with resistive compensation. 


\section{Filter application of the symmetrical OTA}

A filter structure is proposed to demonstrate the advantage of using the resistive compensation technique. The proposed filter based on symmetrical OTA is given in Fig. 7 .

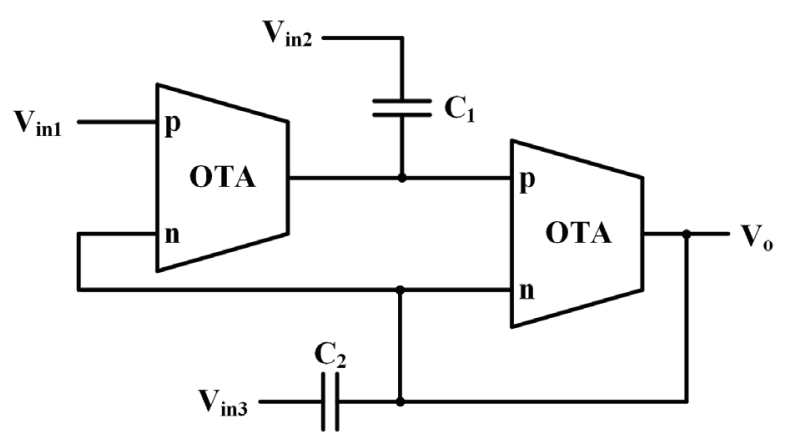

Figure 7: Filter structure based on symmetrical OTA. The proposed circuit can simultaneously realize lowpass, high-pass, and band-pass filter functions. Depending on the voltage status of $\mathrm{V}_{\text {in }{ }^{\prime}}, \mathrm{V}_{\text {in } 2^{\prime}}$ and $\mathrm{V}_{\mathrm{in} 3^{\prime}}$ one of the following three filter functions is realized:

i) $V_{\text {in } 1}=V_{\text {in }}$ and $V_{\text {in2 }}=V_{\text {in } 3}=0$, second order low-pass filter. ii) $V_{\text {in2 }}=V_{\text {in }}$ and $V_{\text {in } 1}=V_{\text {in } 3}=0$, second order band-pass filter. iii) $\mathrm{V}_{\mathrm{in} 3}=\mathrm{V}_{\mathrm{in}}$ and $\mathrm{V}_{\mathrm{in} 1}=\mathrm{V}_{\mathrm{in} 2}=0$, second order high-pass filter.

Fig. 8 shows the gain-frequency responses of all filter structures designed for cutoff frequency of $3.25 \mathrm{MHz}$. The passive capacitor values are chosen as $C_{1}=C_{2}=$ $50 \mathrm{pF}$. Symmetrical OTAs with resistive compensation given in Fig $3 \mathrm{~b}$ are used as active elements.

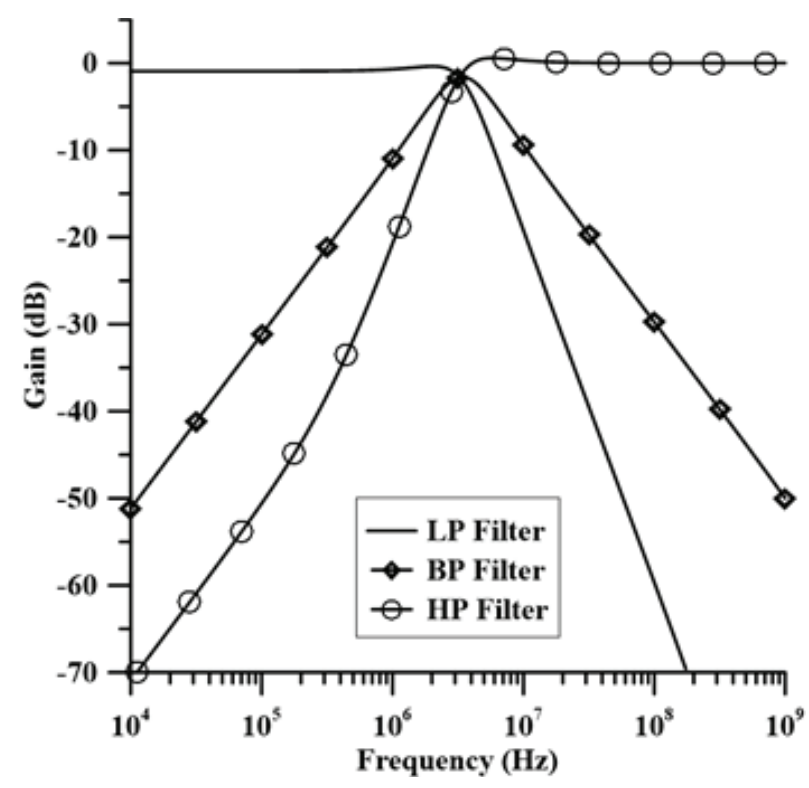

Figure 8: Gain-frequency responses of the symmetrical OTA based filter structures.
The gain-frequency responses of the low-pass filter based on symmetrical OTA with resistive compensation technique for the resistor values of $980 \Omega$ and 1.25 $\mathrm{k} \Omega$ are shown in Fig. 9. The bandwidth of the filter is extended from 3.2 $\mathrm{MHz}$ to $3.9 \mathrm{MHz}$ as shown in Fig. 9b and improved about $18 \%$.

(a)

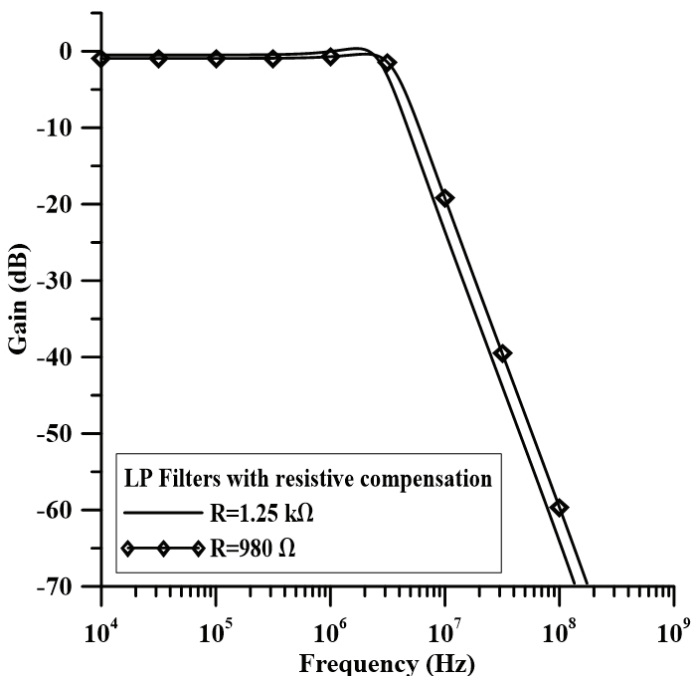

(b)

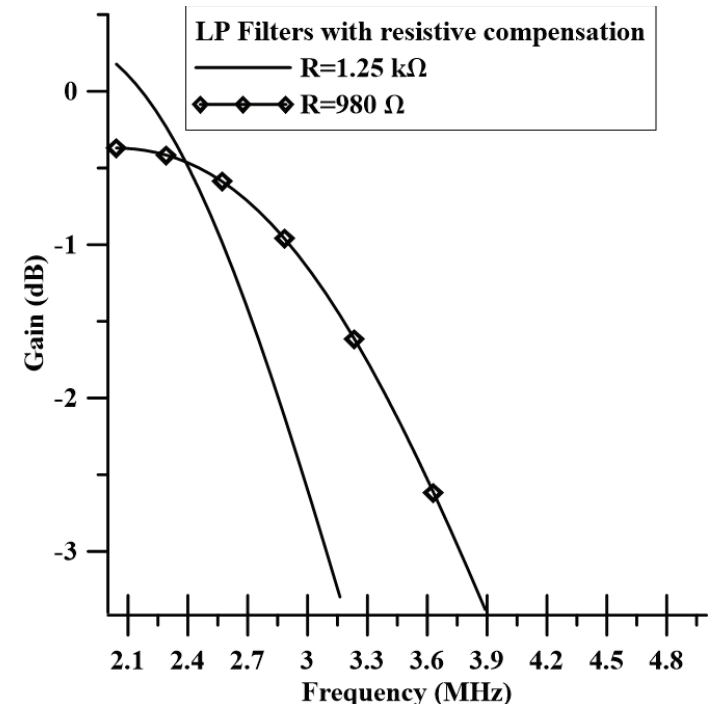

Figure 9: (a) Gain-frequency responses of the low-pass filters based on symmetrical OTA with resistive compensation (b) zoomed-in version.

\section{Conclusion}

In this study, a symmetrical OTA structure with extended transconductance bandwidth is proposed. Resistive compensation technique is applied to the current mirrors of the OTA structure. Due to the use of resistive compensation, bandwidth of the symmetrical OTA is improved. Using resistors and matching them to the $g_{m}$ value adjusted using the biasing currents of the OTA, the bandwidth can be increased. Furthermore, the transconductance value of the OTA with resistive 
compensation is simulated for the varied temperatures and the improved performance is demonstrated. Passive resistors can be replaced by MOS resistors in order to make the circuit suitable for analog integration. Additionally, a low-pass filter circuit is realized with the proposed OTA and the gain-frequency response of the filter is analyzed. Bandwidth of the filter is extended by $18 \%$. The simulations of the symmetrical OTA and filter structures are performed with LTSPICE using $0.18 \mu \mathrm{m}$ TSMC CMOS technology.

\section{Conflict of interest}

We have no conflict of interest to declare.

\section{References}

1. Psychalinos, C., Kasimis, C., \& Khateb, F. (2018). Multiple-input single-output universal biquad filter using single output operational transconductance amplifiers. AEU-International Journal of Electronics and Communications, 93, 360-367. https://doi.org/10.1016/j.aeue.2018.06.037

2. Bano, S., Narejo, G. B., \& Shah, S. U. A. (2019). Low Voltage Low Power Single Ended Operational Transconductance Amplifier for Low Frequency Applications. Wireless Personal Communications, 106(4), 1875-1884. https://doi.org/10.1007/s11277-018-5726-1

3. Ali, H. K., \& Abdaljabar, J. S. (2017). Analysis and Simulation of Active Filters Using Operational Transconductance Amplifier (OTA). European Scientific Journal, 13(15), 170-184.

https://doi.org/10.19044/esj.2017.v13n15p170

4. Mathad, R. S. (2014). Low frequency filter design using operational transconductance amplifier. IOSR Journal of Engineering (IOSRJEN), 4(4), 21-28.

https://doi.org/10.9790/3021-04462128

5. Rezaei, F., \& Azhari, S. J. (2011). Ultra low voltage, high performance operational transconductance amplifier and its application in a tunable Gm-C filter. Microelectronics Journal, 42(6), 827-836. https://doi.org/10.1016/j.mejo.2011.04.012

6. Abuelma'Atti, M. T., \& Quddus, A. (1996). Programmable voltage-mode multifunction filter using two current conveyors and one operational transconductance amplifier. Active and passive electronic components, 19(3), 133-138.

https://doi.org/10.1155/1996/29750
7. Prommee, P., \& Dejhan, K. (2002). An integrable electronic-controlled quadrature sinusoidal oscillator using CMOS operational transconductance amplifier. International Journal of Electronics, 89(5), 365-379.

https://doi.org/10.1080/713810385

8. Abuelma'Atti, M. T., \& Khan, M. H. (1996). Grounded capacitor oscillators using a single operational transconductance amplifier. Active and passive electronic components, 19, 91-98. https://doi.org/10.1155/1996/17943

9. Senani, R., \& Kumar, B. A. (1989). Linearly tunable Wien bridge oscillator realised with operational transconductance amplifiers. Electronics Letters, 25(1), 19-21. https://doi.org/10.1049/el:19890014

10. Babacan, Y. (2018). An Operational Transconductance Amplifier-based Memcapacitor and Meminductor. Electrica, 18(1), 36-38.

https://doi.org/10.5152/iujeee.2018.1806

11. Taskiran, Z. G. C., Ayten, U. E., \& Sedef, H. (2019). Dual-output operational transconductance amplifier-based electronically controllable memristance simulator circuit. Circuits, Systems, and Signal Processing, 38(1), 26-40. https://doi.org/10.1007/s00034-018-0856-y

12. Koomgaew, C., Petchmaneelumka, W., \& Riewruja, V. (2009, August). OTA-based floating inductance simulator. In 2009 ICCAS-SICE (pp. 857-860). IEEE.

13. Jaikla, W., \& Siripruchyanan, M. (2006, October). Floating positive and negative inductance simulators based on OTAs. In 2006 International Symposium on Communications and Information Technologies (pp. 344-347). IEEE.

14. Singh, V. (2003). Floating operational transconductance amplifier based grounded impedance. IEE Proceedings-Circuits, Devices and Systems, 150(1), 27-30. https://doi.org/10.1049/ip-cds:20030367

15. Ettaghzouti, T., Hassen, N., Garradhi, K., \& Besbes, K. (2018). Wide bandwidth CMOS four-quadrant mixed mode analogue multiplier using a second generation current conveyor circuit. Turkish Journal of Electrical Engineering \& Computer Sciences, 26(2), 882-894.

https://doi.org/10.3906/elk-1708-179

16. Gupta, M., Singh, U., \& Srivastava, R. (2014). Bandwidth extension of high compliance current mirror by using compensation methods. Active and passive electronic components, 2014. https://doi.org/10.1155/2014/274795 
17. Voo, T., \& Toumazou, C. (1995). High-speed current mirror resistive compensation technique. Electronics Letters, 31(4), 248-250.

https://doi.org/10.1049/el:19950207

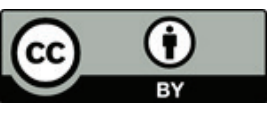

Copyright $\odot 2021$ by the Authors. This is an open access article distributed under the Creative Commons Attribution (CC BY) License (https://creativecommons.org/licenses/by/4.0/), which permits unrestricted use, distribution, and reproduction in any medium, provided the original work is properly cited.

Arrived: 28. 11. 2020

Accepted: 07. 04. 2021 